\title{
A new active volcano in the Tyrrhenian Sea?
}

\author{
Paolo Favali $\left({ }^{1}\right)\left({ }^{2}\right)$, Angelo De Santis $\left({ }^{1}\right)\left({ }^{3}\right)$, Giuseppe D’Anna $\left({ }^{1}\right)$, Bruno Di Sabatino $\left({ }^{3}\right)$, \\ Mario Sedita $\left({ }^{4}\right)$ and Elio Rubino $\left({ }^{5}\right)$ \\ (') Istituto Nazionale di Geofisica e Vulcanologia, Roma, Italy \\ ${ }^{(2)}$ Università degli Studi di Roma «La Sapienza», Roma, Italy \\ $\left(^{3}\right)$ Università degli Studi di Chieti «G. D’Annunzio», Chieti Scalo, Italy \\ $\left(^{4}\right)$ Istituto Nazionale di Fisica Nucleare, Laboratori Nazionali del Sud, Catania, Italy \\ $\left(^{5}\right)$ Elettra TLC SpA, Telecom Italia Group, Roma, Italy
}

\begin{abstract}
A strong earthquake occurred in 2002 off-shore from the northern coast of Sicily in the Southern Tyrrhenian Sea (Italy), and was followed by a series of hundreds of aftershocks. Communications through the fibre-optic cable between Palermo and Rome were interrupted a few hours after the occurrence of the main shock. After the required technical checks, the failure point was found a few kilometres away from the seismic sequence area. A few days later, a specialised cable ship reached the failure area. One side of the cable was completely burnt, while about three kilometres of cable was found locked. Tests on slices of cable showed that the temperature at which the cable was heated went well above $700^{\circ} \mathrm{C}$. We can speculate that the earthquakes triggered off the emission of a submarine lava flow that buried, trapped and burnt the fibre-optic cable. The revising of the bathymetric survey made before the cable's deployment allowed for the identification of a low seamount in the vicinity of the rupture. This structure could represent the lava flow's source volcano.
\end{abstract}

Key words seismicity and volcanic activity in deep marine areas - fibre-optic cable failure - Southern Tyrrhenian Sea

\section{Introduction}

This paper deals with some very interesting observations on a possible seafloor eruption in the Southern Tyrrhenian Sea. We tried to demonstrate, also by laboratory experiments, that the occurrence of a strong off-shore earthquake (September 2002) triggered off a significant lava flow. This flow trapped the Rome-Palermo submarine communication cable, burning it and interrupting communications in the process. These events were part of a long sequence. In fact, 2002 was an

Mailing address: Dr. Paolo Favali, Istituto Nazionale di Geofisica e Vulcanologia, Via di Vigna Murata 605, 00143 Roma, Italy; e-mail: paolofa@ingv.it anomalous year from a geodynamic point of view for the Southern Tyrrhenian Sea and Sicily (Italy). In May of that year the off-shore earthquake was preceded by the strong high-energy «strombolian» activity of Stromboli. It was then followed by an unusually explosive Etna eruption with associated earthquakes starting in October, and by a remarkable degassing episode at Panarea in November. Finally, an unusual lava-flow eruption by Stromboli associated with the sliding of a volcano flank occurred in December. The failure of the volcano's submarine part triggered off a tsunami that caused substantial damage to the island's coastline. It is hard to tell whether there are physical links between all the aspects of this sequence of events; however, this lies beyond the aim of our paper.

\section{Tectonic outline}

The Tyrrhenian Sea is a back-arc basin, with a maximum water depth of around $3600 \mathrm{~m}$, 
Table I. Age (Ma) of the seven Aeolian Islands and some seamounts, arranged from the youngest to the oldest (Beccaluva et al., 1985; Kilburm and McGuire, 2001).

\begin{tabular}{cc}
\hline \hline Island & Age (Ma) \\
\hline Alicudi & 0.06 \\
Vulcano & 0.12 \\
Panarea & 0.15 \\
Lipari & 0.16 \\
Stromboli & 0.23 \\
Palinuro & 0.35 \\
Salina & 0.43 \\
Enarete & 0.73 \\
Eolo & 0.81 \\
Filicudi & 1.02 \\
Sisifo & 1.30 \\
\hline
\end{tabular}

which opened $10 \mathrm{Ma}$ ago. The opening of the basin progressed towards SE in Pleistocene with the formation of the Magnaghi-Vavilov (7-3.5 $\mathrm{Ma}$ ) and the Marsili basins (1.7-1.2 Ma) (Kastens et al., 1988; Mongelli et al., 2004). Its opening has been related to the sinking of the AdriaticIonian lithosphere with a rollback mechanism (Malinverno and Ryan, 1986; Faccenna et al., 1996). The Tyrrhenian Basin is also characterised by high heat flow values, up to over $200 \mathrm{~mW} / \mathrm{m}^{2}$ (Della Vedova et al., 1991; Mongelli et al., 2004).

The Tyrrhenian morphology is complex but similar to larger ocean basins in having an abyssal plain, seamounts and well-developed continental shelves (Marani et al., 2004a-c). The seven Aeolian Islands and the seamounts form a volcanic necklace. They began to develop about one million years ago with the Alicudi Island being the youngest (see table I; Beccaluva et al.,

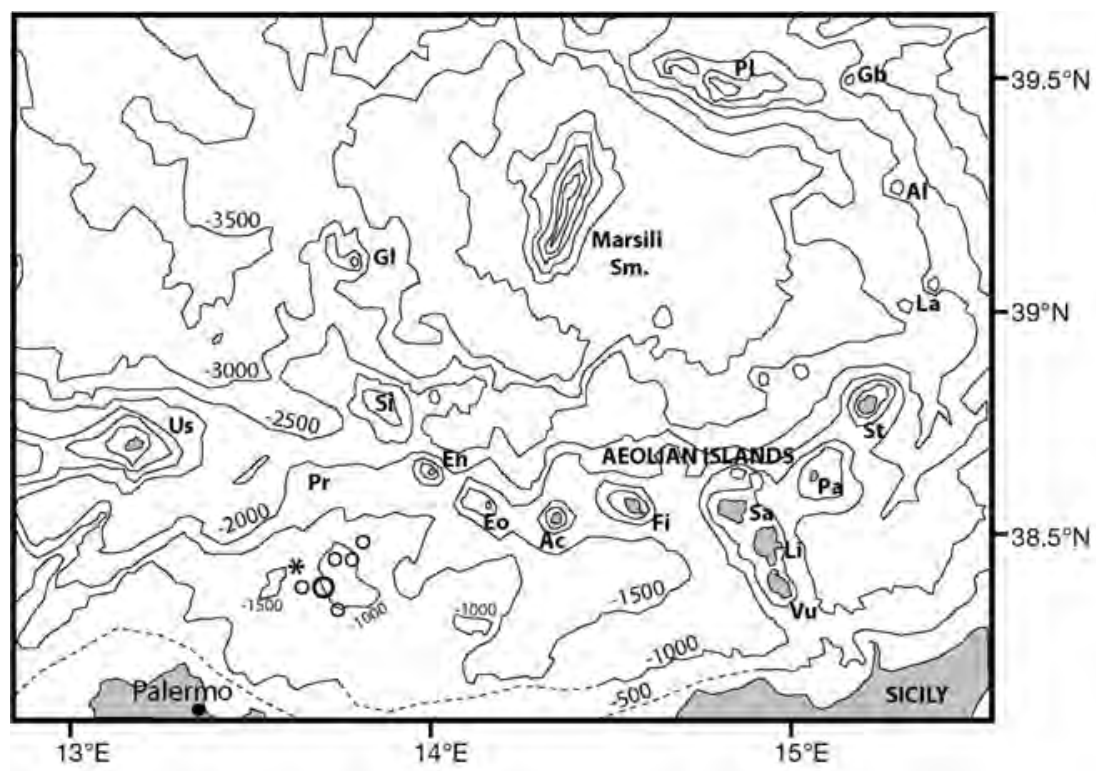

Fig. 1. Sketch of the Southern Tyrrhenian Sea (redrawn simplified from Marani et al., 2004b,c), including coastlines and isobaths (every $500 \mathrm{~m}$ ). All the volcanic islands (in grey in the figure) and submerged seamounts are indicated, except the Vavilov seamount that lies at NW out of the map. Proceeding from NE counter-clockwise: Pl - Palinuro; Gb - Glabro; Al - Alcione; La - Lametini; St - Stromboli; Pa - Panarea; Vu - Vulcano; Li - Lipari; Sa - Salina; Fi - Filicudi; Ac - Alicudi; Eo - Eolo; En - Enarete; Pr - Prometeo; Us - Ustica; Si - Sisifo; Gl - Glauco (Marani and Gamberi, 2004; Trua et al., 2004). The circles represent the main shock $\left(M_{w} 5.9\right)$ and its most energetic aftershocks according to table II, where the errors in $\mathrm{km}$ can be found. The star indicates the cable failure point. 
1985; Kilburn and McGuire, 2001). Besides these islands and Ustica, many volcanic seamounts have been recognised (Marani and Gamberi, 2004). The submerged Aeolian Arc starts from north with the Palinuro volcanic complex (striking E-W for $75 \mathrm{~km}$ ) and Glabro seamount, the easternmost from Palinuro. Then the north-eastern part with three volcanoes, Alcione and the twin cones of the Lametini seamounts, lie in the Calabrian slope. The submerged western arc is aligned in a NW direction and is located to the west of Alicudi Island, and consists of Eolo, Enarete, Sisifo and Glauco seamounts from SE to NW. A lava field, called Prometeo, has been recently discovered between these last sea-mounts and Ustica (Trua et al., 2003). The Aeolian magmas belong to Island Arc Basalt (IAB)-type (Trua et al., 2004). Ustica is an inactive Pleistocene Island, which dates from 0.735 to $0.132 \mathrm{Ma}$ (Etiope et al., 1999). Its volcanics are classified, together with volcanic products of the Prometeo lava field located slightly NW of area studied in this paper, as Island Ocean Basalt (IOB)-type (Trua et al., 2003, 2004). The two central volcanoes, Vavilov (elongated about $30 \mathrm{~km}$ in a N-S direction, with maximum width of $14 \mathrm{~km}$ ) and Marsili (elongated about $60 \mathrm{~km}$ NNE-SSW, with a mean width of $16 \mathrm{~km}$ ), are located in the middle of the two basins Magnaghi-Vavilov at NW and Marsili at SE, respectively (Marani and Gamberi, 2004). Figure 1 shows a sketch of the Southern Tyrrhenian Sea together with some information relevant for this work.

\section{Seismicity}

On September 6, $2002\left(01: 21\right.$ GMT) a $M_{w}$ 5.9 shallow earthquake $(5-10 \mathrm{~km})$ occurred offshore the northern coast of Sicily in the Southern Tyrrhenian Sea, WSW of Alicudi (Azzaro et al., 2004). The seismic event was followed by hundreds of aftershocks over the following three months. The main seismic event struck all of the northern coast of Sicily, even causing some damage in the town of Palermo. In an area $20 \mathrm{~km}$ of radius from the failure cable point, 654 aftershocks were localised by the INGV seismic network up to the end of December 2002 (115 shocks just in the first day). In particular, five earthquakes with magnitude between 3.5 and 4.3 occurred within less than one hour (see table II; INGV, 2005), and the largest aftershock $\left(M_{L} 4.6\right)$ on September 27 (fig. 1).

This seismic activity was very important if compared with the recent past. For instance, in the same area only 59 earthquakes were localised by the same network from January 1, 1994 to September 5, 2002 (maximum magnitude 2.8). This is also true if we consider that the seismic activity of the Tyrrhenian Basin is poorly monitored and localised, due to the presence of an on-shore network alone (Favali et al., 2004). The epicentral area is located WSW of Alicudi roughly in the middle between this island and Ustica Island. In an adjacent area (within $100 \mathrm{~km}$ ) another seismic sequence recently occurred in 1998 with maximum magnitude 4.3 (Agate et al., 2000). In the historical seismic cat-

Table II. List of the major shocks $\left(M_{L} \geq 3.5\right)$ occurring on September 6, 2002 (INGV, 2005); the last column indicates the distance in $\mathrm{km}$ of each seismic event from the rupture in the fibre-optic cable.

\begin{tabular}{ccccc}
\hline \hline Time $(\mathrm{GMT})$ & $M_{L}$ & $\begin{array}{c}\text { Latitude }\left({ }^{\circ} \mathrm{N}\right) \\
(\mathrm{errors} \text { in } \mathrm{km})\end{array}$ & $\begin{array}{c}\text { Longitude }\left({ }^{\circ} \mathrm{E}\right) \\
(\mathrm{errors} \text { in } \mathrm{km})\end{array}$ & $\begin{array}{c}\text { Distance } \\
\text { from the rupture }(\mathrm{km})\end{array}$ \\
\hline $01: 21: 28.6$ & $5.6\left(M_{W}=5.9\right)$ & $38.381( \pm 1.4)$ & $13.701( \pm 1.4)$ & 8.6 \\
$01: 33: 15.9$ & 4.2 & $38.380( \pm 1.9)$ & $13.670( \pm 1.8)$ & 6.4 \\
$01: 39: 53.6$ & 3.9 & $38.339( \pm 2.7)$ & $13.734( \pm 2.9)$ & 13.6 \\
$01: 45: 30.3$ & 4.3 & $38.435( \pm 2.0)$ & $13.731( \pm 1.4)$ & 10.7 \\
$02: 08: 58.2$ & 3.6 & $38.443( \pm 2.3)$ & $13.773( \pm 2.2)$ & 14.4 \\
$02: 15: 53.6$ & 3.5 & $38.490( \pm 1.6)$ & $13.807( \pm 1.2)$ & 19.0 \\
\hline
\end{tabular}


alogue other off-shore earthquakes that affected the northern coast of Sicily are reported; among these the 1726 and 1940 earthquakes were the major events, both with significant damage also affecting Palermo (Boschi et al., 1997; Azzaro et al., 2004). The 2002 earthquake focal mechanism is reversed like all the mechanisms of events located along the northern margin of Sicily, having a contractional axis with an approximately N-S strike (Vannucci et al., 2004). This is in accordance with the area's geodynamic framework (Malinverno and Ryan, 1986; Faccenna et al., 1996; Agate et al., 2000).

\section{Communications cable failure}

Communications between Rome and Palermo broke down at 04:55 GMT, 03:34 hours after the occurrence of the main shock. The total length of the optic cable connecting the two sites is $444.5 \mathrm{~km}$, and 49 segments with four relays subdivide the cable. The fibre-optic cable is a Pirelli Light Weight Protected (LWP). This type of cable is generally used at any sea depth between $1500 \mathrm{~m}$ and $6000 \mathrm{~m}$. It has an optic core with eight fibres placed inside a composite unit, comprising two layers of carbon steel wires and

Table III. Main characteristics of LWP 8-fibre cable.

\begin{tabular}{ccr}
\hline \hline Aluminium tape thickness & $\mathrm{mm}$ & 0.30 \\
Overall diameter (nominal) & $\mathrm{mm}$ & 28.40 \\
Weight in air (approximately) & $\mathrm{kg} / \mathrm{m}$ & 1.10 \\
Weight in water (approximately) & $\mathrm{kg} / \mathrm{m}$ & 0.45 \\
Breaking load & $\mathrm{kN}$ & 100.00 \\
Short-term allowable load $(1 \mathrm{~h})$ & $\mathrm{kN}$ & 85.00 \\
Torque & $\mathrm{Nm} / \mathrm{kN}$ & 0.40 \\
Reverse bend resistance $(r=1 \mathrm{~m})$ & $\mathrm{MPcl}$ & 30.00 \\
Hydrostatic pressure resistance & $\mathrm{MPa}$ & 70.00 \\
Minimum breaking strain of steel wires & $\mathrm{W} / \mathrm{km}$ & 1900.00 \\
Aluminium tape D.C. resistance $\left(10^{\circ} \mathrm{C}\right)$ & $\mathrm{MF} / \mathrm{km}$ & 1.30 \\
Capacitance & $\mathrm{W} / \mathrm{km}$ & 0.20 \\
Composite unit D.C. resistance $\left(10^{\circ} \mathrm{C}\right)$ & & 1.00 \\
\hline
\end{tabular}
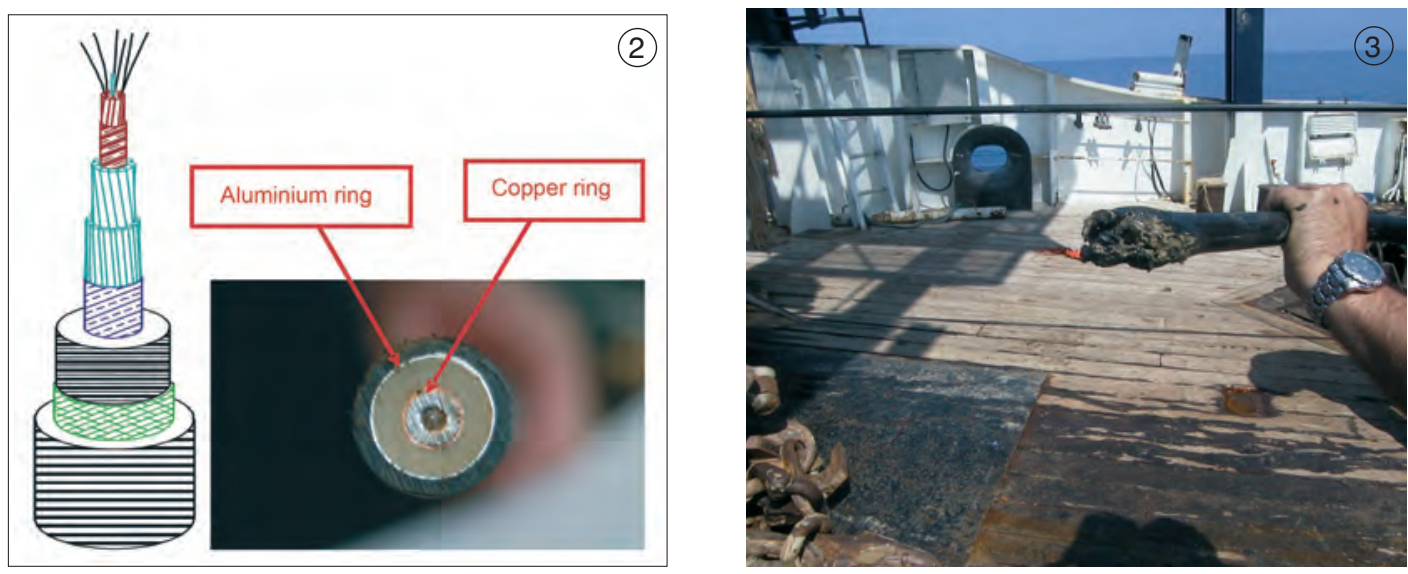

Fig. 2. Picture of the LWP-optic cable (left) and its actual section (right).

Fig. 3. Photograph of the end of the burnt fibre-optic cable taken on board the cable ship just after the recovery. 
a high conductivity copper tube. The main characteristics of the cable are summarised in table III and a picture is shown in fig. 2 together with the actual section.

According to the tests carried out by Palermo Terminal Station (TS) the cable presented all the fibres broken at $41.6 \mathrm{~km}$ from TS and at a depth of about $1450 \mathrm{~m}$, based on the bathymetry performed before the cable deployment. The cable ruptured a few kilometres away from the seismic sequence area (fig. 1). A few days later (on September 14) a cable ship reached the area of the failure to repair the damage. The ship made many attempts to recover the two sides of the broken cable. On the Palermo side, $5051 \mathrm{~m}$ of cable up to the fault were recovered. This end of cable appeared to be been broken by mechanical tension, probably due to the recovery operations. On the Rome side, $3409 \mathrm{~m}$ of cable up to the fault were recovered, whereupon the end was found to be burnt (fig. 3). The optical tests performed from the ship confirmed that $2880 \mathrm{~m}$ of cable had gone missing.

\section{Laboratory test results}

One end of the cable was broken by mechanical tension with almost $3 \mathrm{~km}$ lost, while the oth- er burnt end supports the hypothesis that something locked the cable at a temperature high enough to burn it. In order to confirm whether this hypothesis is feasible and to check the behaviour with temperature of the materials the cable was made of, especially the chemical elements with higher melting temperatures (see table IV; Weast, 1976-1977), we decided to heat different original slices of cable at increasing temperature steps with an oven able to reach high temperature values. The oven reached a maximum temperature of $1100^{\circ} \mathrm{C}$ (Model BE$43 \mathrm{~N}$ Bicasa SpA). The initial steps were $130^{\circ}$, $230^{\circ}, 250^{\circ}, 350^{\circ}$ and $750^{\circ} \mathrm{C}$, at these stages the non metallic parts were seen to melt. To check the fusion time and temperature of the aluminium, we decided to perform another test at $810^{\circ} \mathrm{C}$

Table IV. Density, fusion and ebullition temperatures for copper and aluminium, two of the elements the LWP cable is made of (Weast, 1976-1977).

\begin{tabular}{cccc}
\hline $\begin{array}{c}\text { Chemical } \\
\text { element }\end{array}$ & $\rho\left(\mathrm{g} / \mathrm{cm}^{3}\right)$ & $\begin{array}{c}\text { Fusion } \\
\text { temperature } \\
\left({ }^{\circ} \mathrm{C}\right)\end{array}$ & $\begin{array}{c}\text { Ebullition } \\
\text { temperature } \\
\left({ }^{\circ} \mathrm{C}\right)\end{array}$ \\
\hline Copper $(\mathrm{Cu})$ & 8.92 & $1083.4 \pm 0.2$ & 2567.0 \\
Aluminium $(\mathrm{Al})$ & 2.72 & $660.4 \pm=$ & 2467.0 \\
\hline
\end{tabular}
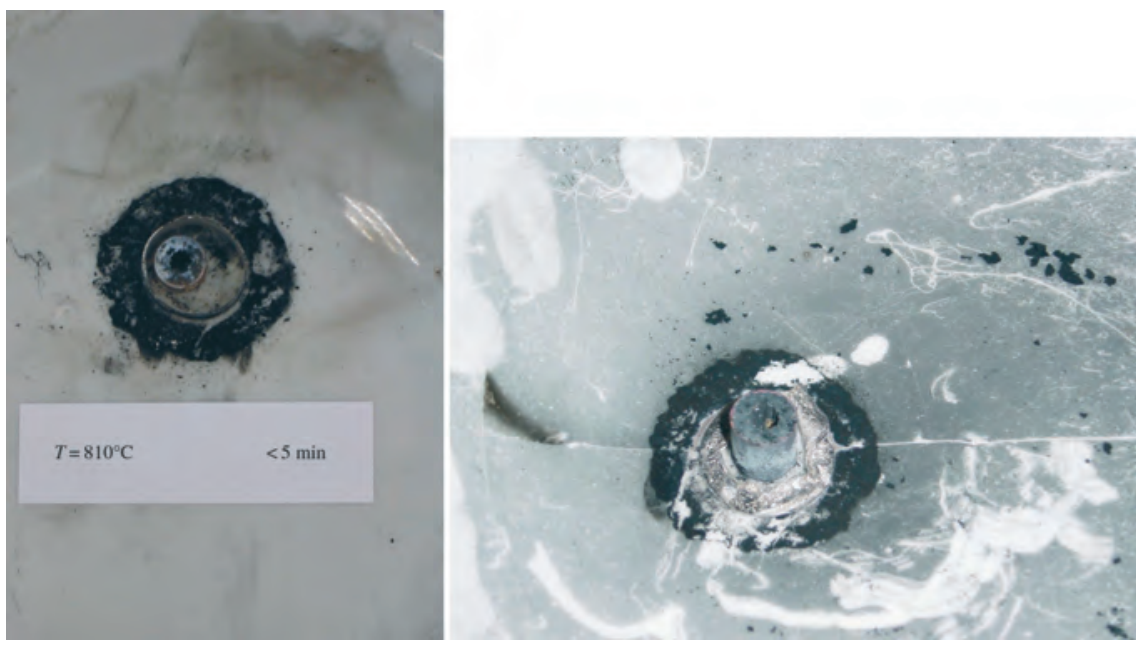

Fig. 4. The results of the oven tests at $810^{\circ} \mathrm{C}$ with time of $5 \mathrm{~min}$ (left) and $15 \mathrm{~min}$ (right). 
leaving the sample there for one, five and fifteen minutes. In the first two steps the time was not enough for the oven temperature to reach the desired level, whereas in the last test the aluminium finally melted. In this latter case, $\mathrm{NaCl}$ was also added (fusion temperature $801^{\circ} \mathrm{C}$ ) to have another independent control of the oven temperature. The results of the steps at $810^{\circ} \mathrm{C}$ with times of five and fifteen minutes are shown in fig. 4 (pictures on the left and right-hand sides, respectively). On the grounds of the test results, we concluded that the minimum temperature (at which the cable was heated) was well over $700^{\circ} \mathrm{C}$ for a length of time significant enough to melt and damage the cable definitively.

\section{Discussion}

The time difference $(3: 34 \mathrm{~h})$ between the main seismic event and the line interruption makes it unlikely that trapping, pulling and breaking of the underwater cable could be due to fractures, faults, collapses directly linked to the seismic events. The distance between the cable and the epicentral area $(\geq 8 \mathrm{~km})$, the imprisonment of the cable the failure to recover more than $2.8 \mathrm{~km}$ cable with an approximately N-S strike, parallel to the maximum inclination of the seabed - the traction and breakage of the cable, the disappearance of the internal resins, the fusion of the cylindrical aluminium ring $\left(T \geq 660^{\circ} \mathrm{C}\right.$, see table IV), the temporal interval between seismic swarm and transmission interruption on the cable, are all data and clues coherent and plausible with a significant deepwater lava flow. Moreover, the same data should underline a good enough fluidity, itself of basaltic-andesitic magmas that are characterised by a temperature of less than or equal to $1100^{\circ} \mathrm{C}$ at emission, and $700-750^{\circ} \mathrm{C}$ at time of tightening.

The seismic activity's time trend (SeptemberDecember 2002) and the seismogram records are typical of a so-called «seismic sequence», perfectly suited to the expected size of the seismogenic structure, with a main shock (the largest in magnitude) and hundreds of aftershocks in a few months (with magnitude over 4.0 in only a few cases). Hence, given the area's seismic «history», the main earthquake and its aftershocks are recognised as being the trigger of the lava effusion. Finally, the shallow epicentral depth (5-10 $\mathrm{km})$ and the time difference between the seismic event and the interruption allow us to evaluate the average speed of lava climbing at $3-8 \mathrm{~km} / \mathrm{h}$. These range values are completely coherent with the distance between the areas of the shock occurrence and the cable failure. Last but not the least, the bathymetric survey that was performed to define the cable route before its deployment

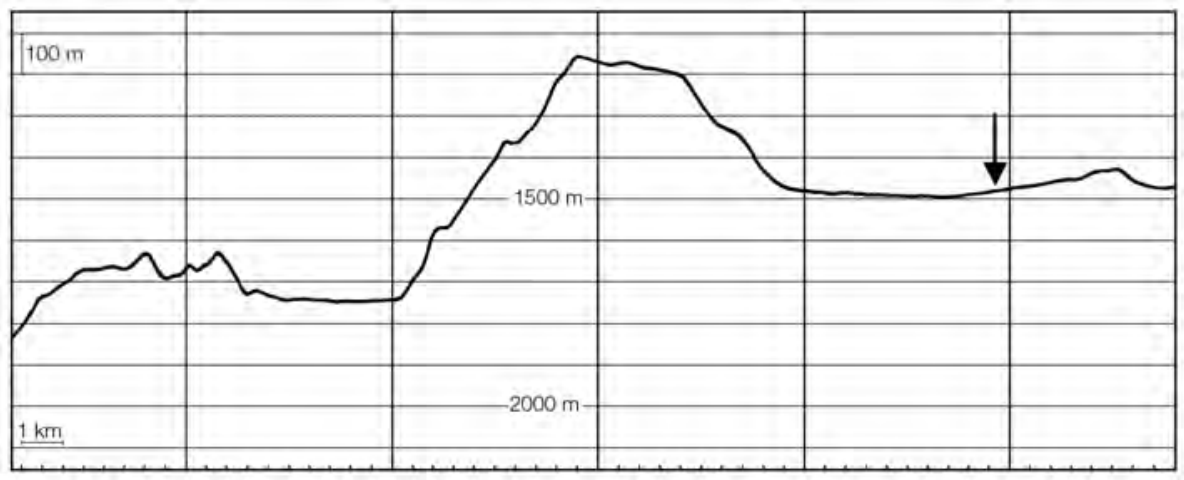

Fig. 5. N-S bathymetric profile parallel to the cable route, based on the data collected to decide the cableway before its deployment. The figure shows, in the middle, a seamount about $10 \mathrm{~km}$ wide (N-S direction) and 0.6 $\mathrm{km}$ high. The arrow roughly indicates the cable rupture area. The vertical scale is exaggerated 10 times with respect to the horizontal scale. 
shows the presence of a low seamount in the proximity of the rupture area (fig. 5). This seamount (about $10 \mathrm{~km}$ wide in $\mathrm{N}-\mathrm{S}$ direction and $0.6 \mathrm{~km}$ high) roughly elongated N-S with steep flanks in the northern and southern edges striking E-W and the physiographic shape of a volcano structure, can be considered as the source of the lava flow. The cable rupture occurred on its flank. Submarine eruptions in the Italian seas are not that unusual, as historical events reported by Mercalli demonstrate (Mercalli, 1883).

\section{Conclusions}

A 5.9 earthquake occurred off-shore WSW Alicudi, and $3 \mathrm{~h}$ later the communications along the main fibre-optic cable connecting Palermo to Rome were interrupted. The repair operations found the cable burnt, with almost $3 \mathrm{~km}$ of cable lost. In an attempt to clarify the cause-effect relationships between the earthquake occurrences and the cable interruption, and to model a feasible explanation, we decided to check the cable's behaviour with the temperature in laboratory tests. By progressively heating up some cable samples up to $810^{\circ} \mathrm{C}$ we demonstrated that the cable had been heated to a minimum temperature well over $700^{\circ} \mathrm{C}$. This temperature excludes the hydrothermal vents as a potential cause of the burning. Therefore, we inferred that the earthquakes had triggered a deepwater lava flow, with this effusion causing the damage, trapping and burning the cable. The presence in the vicinity of the failure point of a volcano-shape seamount can corroborate the hypothesis of this structure as a source of effusion.

Finally this paper shows also the importance of considering geo-hazards (seismicity, volcanic activity and slope instabilities) in planning the deployment of network infrastructures on the seafloor, such as communications cables. This should allow us to avoid unnecessary risks for such infrastructures, also reducing the direct and indirect economic consequences, respectively, the repair and service costs, along with the even higher costs incurred by the breakdown in communication flows.

\section{Acknowledgements}

The Authors are very grateful to the reviewers for their useful comments that have helped us to improve the quality of this paper. We thank F. Frugoni for his helpful suggestions, R. Tozzi for drawing the profile of fig. 5 from bathymetric data, and M. Liberatore for his help in carrying out the laboratory testing.

\section{REFERENCES}

Agate, M., L. Beranzoli, T. Braun, R. Catalano, P. Favali, F. Frugoni, F. Pepe, G. Smriglio and A. Sulli (2000): The 1998 off-shore NW Sicily earthquakes in the tectonic framework of the southern border of the Tyrrhenian Sea, Mem. Soc. Geol. Ital., 55, 103-114.

Azzaro, R., M.S. Barbano, R. Camassi, S. D'Amico, A. Mostaccio, G. Piangiamore and L. Scarfi (2004): The earthquake of 6 September 2002 and the seismic history of Palermo (Northern Sicily, Italy): implications for the seismic hazard assessment of the city, $J$. Seismol., 8, 525-543.

Beccaluva, L., G. Gabbianelli, F. Lucchini, P.L. Rossi and C. SAVELLI (1985): Petrology and K/Ar ages of volcanics dredged from the Aeolian seamounts: implications for geodynamic evolution of the Southern Tyrrhenian Basin, Earth Planet. Sci. Lett., 74, 187-208.

Boschi, E., E. Guidoboni, G. Ferrari, G. VAlensise and P. GASPERINI (1997): Catalogue of the Strong Earthquakes in Italy from 461 BC to 1990 (ING, RomaSGA, Bologna), pp. 973.

Della Vedova, B., F. Mongelli, G. Pellis, P. Squarci, L. TAFFI and G. ZiTo (1991): Heat Flow Map of Italy (Int Inst. Geotherm. Res.-CNR, Pisa).

Etiope, G., P. Beneduce, M. Calcara, P. Favali, F. FrugoNi, M. Schiattarella and G. Smriglio (1999): Structural pattern and $\mathrm{CO}_{2}-\mathrm{CH}_{4}$ degassing of Ustica Island, Southern Tyrrhenian Basin, J. Volcanol. Geotherm. Res., 88, 291-304.

Faccenna, C., P. Davy, J.-P. Brun, R. Funiciello, D. GiaRDINI, M. MatTeI and T. NAlPAs (1996): The dynamics of back-arc extensions: an experimental approach to the opening of the Tyrrhenian Sea, Geophys. J. Int., 126, 781-795.

Favali, P., L. Beranzoli and A. Maramai (2004): Review of the Tyrrhenian Sea seismicity: how much is still to be unknown?, in From Seafloor to Deep Mantle: Architecture of the Tyrrhenian Back-arc Basin, edited by Marani, M.P., F. Gamberi and E. Bonatti, Mem. Descr. Carta Geol. Ital., LXIV, 57-70.

INGV (Istituto Nazionale di Geofisica e Vulcanologia) (2005) Bulletin of the Italian Seismic Activity (available on line: http://www.ingv.it).

Kastens, K., J. Mascle, C. Auroux, E. Bonatti, C. Broglia, J. Channell, P. Curzi, K.C. Emeis, G. Glacon, S. Asegawa, W. Heike, G. Mascle, F. McCoy, J. McKenzie, J. Mendelson, C. Muller, J.P. Rehault, A. Robertson, R. SARTori, R. Sprovieri and M. ToriI 
(1988): ODP Leg107 in the Tyrrhenian Sea: insights into passive margin and back-arc basin evolution, $G e$ ol. Soc. Am. Bull., 100, 1140-1156.

KILBURN, C.J. and W.J. McGuiRE (2001): Italian Volcanoes (Classic Geology in Europe 1), (Terra Publishing, Harpenden, England), pp. 160.

MALINVERnO, A. and W.B.F. RYAN (1986): Extension in the Tyrrhenian Sea and shortening in the Apennines as result of arc migration driven by sinking of the lithosphere, Tectonics, 5, 227-245.

MARANi, M.P. and F. GAMBERI (2004): Distribution and nature of submarine volcanic landforms in the Tyrrhenian Sea: the arc versus the back-arc, in From Seafloor to Deep Mantle: Architecture of the Tyrrhenian Back-arc Basin, edited by M.P. MARANI, F. GAMBERI and E. BONATTI, Mem. Descr. Carta Geol. Ital., LXIV, 109-126.

Marani, M.P., F. Gamberi and E. BonatTi (Editors) (2004a): From seafloor to deep mantle: architecture of the Tyrrhenian back-arc basin, Mem. Descr. Carta Geol. Ital., LXIV, pp.195.

Marani, M.P., F. Gamberi, G. Bortoluzzi, G. CARrara, M. Ligi and D. Penitenti (2004b): Seafloor morphology of the Tyrrhenian Sea (1:1000000), in From Seafloor to Deep Mantle: Architecture of the Tyrrhenian Backarc Basin, edited by M.P. MARANI, F. GAMBERI and E. BonatTI, Mem. Descr. Carta Geol. Ital., LXIV, pp.195.

Marani, M.P., F. Gamberi, G. BortoluzZi, G. CARrara, M. Ligi and D. Penitenti (2004c): Tyrrhenian Sea bathymetry (1:1000000), in From Seafloor to Deep Mantle: Architecture of the Tyrrhenian Back-arc Basin, ed- ited by M.P. Marani, F. Gamberi and E. Bonatti, Mem. Descr. Carta Geol. Ital., LXIV, pp. 195.

Mercalli, G. (1883): Vulcani e Fenomeni vulcanici, in Geologia d'Italia, edited by G. NEGRI, A. STOPPANI and G. Mercalli (Editrice F. Vallardi, Milano), 117-123.

Mongelli, F., G. Zito, S. De Lorenzo and C. Doglioni (2004) Geodynamic interpretation of the heat flow in the Tyrrhenian Sea, in From Seafloor to Deep Mantle: Architecture of the Tyrrhenian Back-arc Basin, edited by M.P. Marani, F. Gamberi and E. Bonatti, Mem. Descr. Carta Geol. Ital., LXIV, 71-82.

Trua, T., G. SERri and M.P. MARANI (2003): Lateral flow of African mantle below the nearby Tyrrhenian plate: geochemical and isotopic evidence, Terra Nova, 15, 433-440.

Trua, T., G. Serri and P.L. Rossi (2004): Coexistence of IAB-type and IOB-type magmas in the Southern Tyrrhenian back-arc basin: evidence from recent seafloor sampling and geodynamic implications, in From Seafloor to Deep Mantle: Architecture of the Tyrrhenian Back-arc Basin, edited by M.P. MARANI, F. GAMBERI and E. BonatTI, Mem. Descr. Carta Geol. Ital., LXIV, 83-96.

Vannucci, G., S. Pondrelli, A. Argnani, A. Morelli, P. GASPERINI and E. Boschi (2004): An Atlas of Mediterranean seismicity, Ann. Geophysics, 47 (suppl. to no. 1), 247-334.

WEAST, R.C. (Editor) (1976-1977): Handbook of Chemistry and Physics (Section B) (CRC Press, Cleveland), 57th edition, pp. 439. 